\begin{tabular}{|c|c|c|}
\hline $\begin{array}{l}\text { PUCRS } \\
\text { PUCR }\end{array}$ & $\begin{array}{l}\text { ESCOLA DE } \\
\text { HUMANIDADES }\end{array}$ & $\begin{array}{l}\text { Revista Digital do Programa de Pós-Graduação em Letras da PUCRS } \\
\text { Letrônica, Porto Alegre, v. 13, n. 1, p. 1-13, jan.-mar. } 2020 \\
\text { e-ISSN: } 1984-4301\end{array}$ \\
\hline del $h$ & org/10.15448/1984-4301.2020.1.35133 & \\
\hline
\end{tabular}

\title{
Disputas epistemológicas e ecologia dos saberes em dois romances de autoria de mulheres no Brasil
}

\author{
Epistemological disputes and ecology of knowledges \\ in two novels written by women in Brazil \\ Disputas epistemológicas y ecología de saberes en \\ dos novelas de autoría de mujeres en Brasil
}

\section{Aline Veingartner \\ Fagundes $^{1}$}

orcid.org/0000-0002-9093-897X

aline.veingartner@gmail.com

Recebido em: 30 jul. 2019. Aprovado em: 22 nov. 2019. Publicado em: 7 abr. 2020.

\begin{abstract}
Resumo: Sob uma perspectiva decolonial, este artigo visita dois romances escritos por autoras brasileiras cujas protagonistas são também mulheres: Amrik, da cearense Ana Miranda, e Ponciá Vicêncio, da mineira Conceição Evaristo. As noções de disputas epistemológicas e ecologia dos saberes de Boaventura de Sousa Santos servem de impulso para identificar quais conhecimentos estão em jogo nas narrativas e compreender de que maneira se relacionam, se mesclam ou se contrapõem aos conhecimentos ocidentais hegemônicos. Esta análise política e literária nos mostra que a diversidade do mundo, em seu caráter inesgotável, não admite uma única epistemologia adequada, mas demanda uma ecologia dos saberes que abranja a também inesgotável diversidade de experiências não canônicas de conhecimento.
\end{abstract}

Palavras-chave: Literatura brasileira. Ana Miranda. Conceição Evaristo. Disputas epistemológicas. Ecologia dos saberes.

Abstract: In a decolonial perspective, this article visits two novels, written by Brazilian authors, whose protagonists are also women: Amrik, by Ana Miranda, and Ponciá Vicêncio, by Conceição Evaristo. The notions of epistemological disputes and the ecology of knowledge of Boaventura de Sousa Santos serve as an impetus to identify which knowledge is at stake in the narratives and to understand how they relate, blend or oppose western hegemonic knowledge. This political and literary analysis shows us that the diversity of the world, in its inexhaustible character, does not admit a single adequate epistemology, but demands an ecology of knowledge that encompasses the equally inexhaustible diversity of non-canonical experiences of knowledge.

Keywords: Brazilian literature. Ana Miranda. Conceição Evaristo. Epistemological disputes. Ecology of knowledge.

Resumen: Bajo una perspectiva decolonial, este artículo visita dos novelas, escritas por autoras brasileñas, cuyas protagonistas son también mujeres: Amrik, de Ana Miranda, y Ponciá Vicêncio, de Conceição Evaristo. Las nociones de disputas epistemológicas y ecología de saberes de Boaventura de Sousa Santos nos dan impulso para identificar los conocimientos que están en juego en las narrativas y comprender de que forma se relacionan, se mezclan o se contraponen a los conocimientos occidentales hegemónicos. Este análisis político y literario nos muestra que la diversidad del mundo, en su carácter inagotable, no admite una única epistemología adecuada, sino que demanda una ecología de saberes que abarque la también inagotable diversidad de experiencias no canónicas de conocimiento.

Palabras clave: Literatura brasileña. Ana Miranda. Conceição Evaristo. Disputas epistemológicas. Ecología de saberes. 


\section{Introdução}

".... não sabia pensar, como se o raciocinio fosse infinitamente inferior ao que se passava dentro de mim". (Ana Miranda) ${ }^{2}$

Os romances brasileiros que escolhi visitar para inspirar esta reflexão - Amrik, da cearense Ana Miranda, publicado pela primeira vez em 1997, e Ponciá Vicêncio, da mineira Conceição Evaristo, publicado pela primeira vez em $2003^{3}$ - compartilham o fato de serem protagonizados por personagens femininas inesqueciveis na literatura brasileira no século $X X^{4}$ e a possibilidade de levantar discussões a partir de uma ótica decolonial. Minha intenção, portanto, é pinçar alguns momentos especíicos das narrativas que nos ajudem a observar como são representadas as disputas epistemológicas e em que medida poderiamos dizer que mobilizam uma ideia de ecologia dos saberes conforme a proposta de Boaventura de Sousa Santos.

Em capítulo da coletânea Epistemologias do Sul, Santos (2009, p. 23) sustenta que "o pensamento moderno ocidental é um pensamento abissal", cuja principal característica é a impossibilidade de que o universo de um lado da linha coexista com o universo do outro lado da linha. O pensamento abissal, que tem no campo do conhecimento uma de suas manifestações, outorga à ciência moderna o monopólio da divisão universal entre o que é verdadeiro e o que é falso. Assim, desenrolamse disputas epistemológicas entre as formas cientíicas e as formas não científicas de verdade.

Ao discorrer sobre as tensões entre a ciência, a filosofia e a teologia, o autor indaga acerca da relação estabelecida entre a verdade científica e as outras verdades possiveis que não podem ser estabelecidas conforme o método cientíico. Essas disputas, que ocorrem neste lado da linha, estão calcadas na invisibilidade de outras formas de conhecimentos, como os saberes populares, os camponeses ou os indigenas, por exemplo, que se situam do outro lado da linha. Com efeito, tais saberes desaparecem como conhecimentos relevantes e nem chegam a ser considerados reais; para o pensamento moderno, não passam de "crenças, opiniões, magia, idolatria, entendimentos intuitivos ou subjetivos" (SANTOS, 2009, p. 25), já que não obedecem aos preceitos científicos de verdade nem aos critérios estabelecidos pelos conhecimentos filosóficos e teológicos.

Essas divisões são consideradas abissais por aniquilarem as realidades localizadas do outro lado da linha. O que Santos (2009, p. 29) compreende como o outro lado da linha está relacionado com a zona colonial, este "universo das crenças e dos comportamentos incompreensiveis que de forma alguma podem considerar-se conhecimento, estando, por isso, para além do verdadeiro e do falso". O estranhamento provocado por tais práticas ininteligiveis nos homens metropolitanos, que liam os "selvagens" como sub-humanos, teria tido como consequência a desumanização de seus agentes. As invasões e as ocupações dos territórios indigenas, por exemplo, seriam justificadas por essa concepção. A negação radical de uma parte da humanidade - essa que residiria no outro lado da linha, na zona colonial - se torna, assim, a condição para que a outra parte da humanidade possa se afirmar enquanto universal.

Para Santos (2009), os territórios colonizados foram marcados pela tensão entre apropriação e violência em diferentes formatos em cada tempo e espaço. Ações de incorporação, cooptação e assimilação estariam implicadas na ideia de apropriação, ao passo que ações de destruição física, material, cultural e humana estariam relacionadas à noção de violência. Ambos os termos da dicotomia estão profundamente interligados. Para ilustrar como essas ações ocorrem na prática, temos os seguintes exemplos:

\footnotetext{
MIRANDA, Ana. Amrik. 2. ed. São Paulo: Companhia das Letras, 2011.

3 As edições consultadas dos romances foram as dos anos 2011 e 2018, respectivamente, conforme consta nas referências deste texto.

4 Embora 2003 seja a data de sua primeira publicação, de acordo com Bárbara Araújo Machado (2014), o romance foi escrito ao longo de 1988, ano do centenário da abolição da escravidão e da promulgação da "Constituição Cidadã" no Brasil: "Enquanto Becos da Memória foi o primeiro romance a ser escrito por Conceição Evaristo, o primeiro a ser publicado por ela foi Ponciá Vicêncio. O livro foi escrito ao longo do ano de 1988, na mesma época, portanto, que a escrita de Becos" (MACHADO, 2014, p. 92). Dada a importância histórica do ano de 1988, considero Ponciá Vicêncio uma obra do século XX.
} 
No domínio do conhecimento, a apropriação vai desde o uso de habitantes locais como guias e de mitos e cerimónias locais como instrumentos de conversão, à pilhagem de conhecimentos indigenas sobre a biodiversidade, enquanto a violência é exercida através da proibição do uso das línguas próprias em espaços públicos, da adoção forçada de nomes cristãos, da conversão e destruição de simbolos e lugares de culto, e de todas as formas de discriminação cultural e racial (SANTOS, 2009, p. 29).

O autor argumenta que essa realidade não se limita ao periodo colonial, mas persiste até hoje. 0 modelo de exclusão representado pelas colônias sobrevive no pensamento, nos principios e nas práticas modernas ocidentais, que se pretendem hegemônicas. Para Santos (2009), portanto, as linhas abissais globais continuam a estruturar 0 conhecimento moderno e a constituir as relações políticas e culturais protagonizadas pelo Ocidente no interior do sistema mundial. A seguir, vamos analisar de que maneira essas discussões se relacionam com as obras Ponciá Vicêncio e Amrik.

\section{Dois romances, muitas disputas}

O Brasil, enquanto território colonizado pela Europa, é herdeiro direto de um pensamento colonial moderno. De acordo com Quijano (2005), a perspectiva de conhecimento eurocêntrica marcada por uma racionalidade específica, com as suas categorias binárias próprias - se tornou mundialmente hegemônica e se sobrepôs a todas as demais formas de conhecimento. Assim, os romances analisados são palco de disputas epistemológicas: de um lado, formas científicas de verdade e valores da doutrina cristã, que foram impostos pela metrópole portuguesa e que passaram a integrar a subjetividade dos povos colonizados; e, de outro, formas não científicas de verdade, saberes não ocidentais e valores não cristãos.

Em um contexto pós-colonial, como no caso das duas ficções, foi apenas na teoria que o Brasil deixou de ser colônia. Por isso, a racionalidade eurocêntrica continua se reproduzindo nas instituições sociais, no imaginário, nas relações intersubjetivas e nas práticas dos sujeitos. No entanto, conforme flagramos nos romances, essa perspectiva de conhecimento não é totalizadora, mas se confronta ou se combina com outros sistemas não canônicos de conhecimento, que compõem as epistemologias dos povos originários, dos escravizados que foram forçadamente trazidos de países do continente africano no periodo escravocrata e dos imigrantes que posteriormente chegaram ao Brasil.

O romance Ponciá Vicêncio, de Conceição Evaristo, foi publicado pela primeira vez em 2003. depois de ter passado mais de dez anos guardado na gaveta da escritora. No prefácio da terceira edição, Evaristo (2018, p. 8-9) destaca o sentido político da literatura de autoria de mulheres tendo em vista a maciça presença de autores homens encabeçando os números do cenário literário. Para a escritora, o ato de publicar é igualmente imbuido de sentido político para as mulheres, já que existem entraves relacionados a suas condições étnicas e sociais, que tornam ainda mais árdua a oportunidade de ter as suas escritas editadas e reconhecidas.

Além do recorte de gênero, há também o racial. Em entrevista concedida a Nahima Maciel (2018), Conceição Evaristo aborda a dificuldade de as mulheres negras serem vistas pelo mercado editorial como legítimas produtoras de conhecimento em um país racista em suas estruturas. A autora então deixa claro que é intencional o seu projeto político no campo da literatura, evidenciado no cuidado com a linguagem de seus textos e na criação de personagens negros não estereotipados, que são alçados ao lugar de humanidade frequentemente negada em outras representações literárias.

Já em Amrik, de Ana Miranda, entram em cena os desdobramentos de uma questão muitas vezes ignorada quando pensamos na formação cultural brasileira: a imigração libanesa. O romance, publicado pela primeira vez em 1997, traz ao final da edição de 2011 uma nota esclarecendo que a infância da narradora Amina Salum, vivida em uma aldeia libanesa, foi inspirada nas recordações de quatro mulheres libanesas e nas cartas de uma viajante inglesa que esteve no Libano em 1886. Em seguida, apresenta uma considerável lista de publicações que foram úteis para a construção 
da ficção e um glossário de quase cem palavras, a maioria de origem árabe. As obras consultadas pela escritora abordam, entre outros temas, a culinária, a cultura, a história e a literatura dos povos de origem árabe.

Em entrevista a Mauricio Meireles, Ana Miranda ([2014]) afirma que tem preferência pelas vozes femininas, em contraposição às vozes literárias canônicas, quase completamente masculinas, e também pela narração em primeira pessoa, que não seria indicada, segundo a tradição, para romances históricos como os que ela escreve. Outro ponto de destaque nessa entrevista é que, para a escritora, "O que não for cantado ou desaparece, ou perde o significado. O que não é transformado em arte, ciência, história... Vai se perdendo nas caligens do tempo" (MIRANDA ([2014]). Com isso, apesar de não deixar explícita uma visão da escrita e a publicação como atos políticos, como o faz Evaristo, é possivel vislumbrar na fala de Miranda um projeto de resgate e visibilidade de elementos apagados na história de nosso País - sobretudo considerando que os povos de origem árabe e as suas tradições sofreram processos de silenciamento e de violência epistêmica em alguma medida similares aos sofridos pelas Américas colonizadas.

Dessa forma, as disputas que mobilizo em Amrik estão presentes nas concepções de corpo, dança e intelecto, bem como entre uma epistemologia de raizes árabes em contraposição à epistemologia ocidental hegemônica presente no Brasil. Em Ponciá Vicêncio, por sua vez, estão relacionados especialmente a um embate entre a cultura e religião ocidental branca e os conhecimentos e a religiosidade afrodescendente, desdobrando-se em outras manifestações, como a ancestralidade, a oralidade e os saberes do barro. Assim, ao contestar e desafiar os conhecimentos oficialmente aceitos, em ambas as ficções, como veremos na sequência, parece estar implícita uma proposta de ruptura com a perspectiva colonial eurocêntrica.

\section{Ancestralidade, oralidade e tradições não ocidentais}

De acordo com Lélia Gonzalez (1988, p. 71), durante o colonialismo europeu, o racismo foi constituído como a "'ciência' da superioridade eurocristã (branca e patriarcal)". Esse processo teria ocorrido no âmago de uma tradição etnocêntrica que via as manifestações culturais dos povos "selvagens" como absurdas, supersticiosas ou exóticas. Com efeito, o racismo foi uma das estratégias usadas pelos paises europeus para a manutenção da dominação colonial, uma vez que operava nos colonizados um processo de internalização da "superioridade" do colonizador.

A autora lembra que, nas diferentes sociedades do nosso continente, a violência do racismo despojou os seus povos de seu legado histórico, a sua dignidade, a sua história e as suas contribuições para o avanço da humanidade nos âmbitos da filosofia, da ciência, das artes e das religiões. Nesse sentido, em ambos os romances, é possivel notar uma resposta ativa às tentativas de despojamento dos legados históricos das culturas afrodescendentes, em Ponciá Vicêncio, e da cultura dos povos de origem árabe, em Amrik.

Um dado extraliterário relevante nesse sentido pode ser encontrado na entrevista concedida por Conceição Evaristo ao programa Estação Plural ${ }^{5}$. Ao conversar com os entrevistadores sobre a personagem Ponciá Vicêncio e o não reconhecimento de seu sobrenome, que era uma "reminiscência do poderio do senhor, um tal coronel Vicêncio" (EVARISTO, 2018, p. 26), Evaristo denuncia a imposição de nomes cristãos em detrimento dos nomes dos africanos escravizados e de seus descendentes, que foram perdidos, assim como as suas linguas maternas. Diferentemente dos descendentes de imigrantes europeus, que puderam manter as suas referências, a sua memória histórica, que sabiam exatamente de qual país da Europa vinham, os descendentes de africanos - como a própria escritora - não sabem de qual pais da África são os seus antepassados, pois esses

5 Disponivel em: https://www.youtube.com/watch?v=Xn2gj1hGsoo\&t=2530s. Acesso em: 9 jul. 2019. 
foram trazidos à força ao Brasil e nada puderam carregar consigo além da memória oral. Nesse sentido, a escolha por nomes de origens africanas para as personagens de suas obras pode ser vista como uma resposta à adoção forçada de nomes cristãos e outras formas de despojamento cultural mencionadas por Santos (2009).

\subsection{Ponciá Vicêncio}

Iniciamos a reflexão sobre o romance de Conceição Evaristo no ponto da narrativa em que os missionários chegam ao povoado onde vive a familia da protagonista e montam uma escola para ensinar a população a ler. Ponciá Vicêncio, ainda criança, decide aprender o abecedário. Os conhecimentos são divididos pela mãe de Ponciá entre os saberes da roça e saberes da cidade. Enquanto a leitura e a escrita são associadas por ela aos saberes da cidade, que exige essas habilidades, os saberes da roça são relacionados com os ciclos das plantações e das colheitas: o importante, nesse contexto, é conhecer "as fases da lua, o tempo de plantio e de colheita, o tempo das águas e das secas" (EVARISTO, 2018, p. 25). Embora sejam colocados em categorias distintas, os saberes da cidade e os saberes da roça não são hierarquizados aqui: a mãe reconhece que cada um têm sua aplicabilidade a depender do espaço e de suas demandas.

Os personagens também parecem se relacionar de maneira ambígua com a religiosidade: por um lado, são receptivos à fé cristã, acolhendo os padres missionários que ensinam o povoado a ler, casam os casais antes amigados, batizam e comungam as crianças e ungem os doentes; por outro, respeitam a autoridade espiritual, a ancestralidade e os conhecimentos da anciã Nêngua Kainda, buscando as suas garrafadas, as suas bênçãos, os seus conselhos e as suas previsões para o futuro. Até mesmo o irmão da protagonista, Luandi, que chega a questionar a sabedoria de Nêngua Kainda, acreditando que com ele a velha havia se enganado, por fim, reconhece o sentido de suas palavras quando ela lhe alertara que "estava num caminho que não era o dele" (EVARISTO, 2018, p. 81). Assim, vemos que os personagens convivem com religiões de duas matrizes distintas, a cristã e a afro-brasileira, sem que a primeira se sobreponha à segunda, e negociam as suas práticas conforme a disponibilidade de cada uma e de suas necessidades próprias.

Outro momento de destaque da narrativa é quando Luandi chega à cidade e se admira com Nestor, o soldado negro. Era para ele uma combinação antes impensável, talvez porque os saberes e as práticas implicados nessa profissão estivessem relacionados, em seu imaginário, com a imagem de um homem branco: andar bonito, marchar, saber ler, assinar "o nome de maneira rápida e bonita" (EVARISTO, 2018, p. 58), mandar, prender, bater, "ter a voz alta e forte como a dos brancos" (EVARISTO, 2018, p. 62). A partir desse momento, Luandi deseja ser também um soldado verdadeiro, gente importante, gente de mando (EVARISTO, 2018, p. 68). A propósito desse tema, Nelson Maldonado-Torres (2018, p. 38) aponta que "a modernidade/colonialidade é um paradigma de guerra que se coloca como justo e que faz o contexto colonial sempre violento, uma situação que normaliza a violência bem além das fronteiras das colônias e ex-colônias". Nesse contexto, a guerra é naturalizada e os sujeitos colonizados acabam por adotar costumes e modos de pensar dos colonizadores, perpetrando ainda mais violência.

Assim, é possivel imaginar que o desejo alimentado por Luandi de se tornar soldado e adotar práticas fundamentalmente violentas tenha a ver com uma internalização dessa lógica e desse ethos colonizador, que a seus olhos parece trazer mais beneficios do que a sua posição de colonizado. Aqui falamos não somente de colonialidade, materializada nos valores eurocêntricos impostos nas dimensões do poder, do ser e do saber dos povos das Américas, mas também de raça, já que são os personagens brancos que encarnam esses valores no romance. Assim, o fato de um homem negro se tornar soldado se revela como uma ruptura na expectativa de Luandi e também de sua mãe que, na roça, só "tinha visto negros trabalhando para brancos, sempre sob as ordens de um senhor, que 
estivesse perto ou não" (EVARISTO, 2018, p. 100).

O desejo de ser um soldado, no entanto, se dissolve no reencontro com a irmã no final do romance. Luandi relembra o alerta de Nêngua Kainda, de que esse não era seu caminho, e tem um importante insight: "Soldado Nestor era tão fraco e tão sem mando como ele. Apenas cumpria ordens, mesmo quando mandava, mesmo quando prendia" (EVARISTO, 2018, p. 109). A velha sábia the advertira de que nada adiantaria ter voz de mando, se investir dos saberes e das práticas dos brancos, se no final das contas levantaria o chicote contra os corpos dos seus, das vozesirmãs sofridas (EVARISTO, 2018, p. 81). Em sintonia com as palavras de Nêngua Kainda, Luandi faz então importantes descobertas: "A vida era um tempo misturado do antes-agora-depois-e-dodepois-ainda. A vida era a mistura de todos e tudo. Dos que foram, dos que estavam sendo e dos que viriam a ser" (EVARISTO, 2018, p. 110) - uma perspectiva que leva em conta a ancestralidade e a importância de não reproduzir práticas que subjugariam e violentariam os seus semelhantes.

\subsection{Amrik}

Em Amrik, uma das personagens que cumpre o papel de conectar a protagonista com a sua ancestralidade e a sua origem é vovó Farida, cujas lições e aconselhamentos Amina guarda por toda a vida narrada. A dança e a culinária, as duas grandes paixões da protagonista, são saberes transmitidos oralmente por essa figura feminina mais velha. O papel da avó será discutido no próximo tópico deste artigo. Aqui, vamos nos concentrar em uma figura masculina de relevo para a formação dos conhecimentos e principios de Amina em explícita contraposição aos dogmas ocidentais: o cego e sábio tio Naim.

Em "Camelos, Amantes", a protagonista nos conta que, apesar de ter levado na viagem quase duzentos livros de diversas procedências, o tio privilegia a leitura das obras árabes. A justificativa de tio Naim - "Para não perder o amor por tua terra" (MIRANDA, 2011, p. 30) - parece estar relacionada a um esforço de se manterem conectados com as suas raizes, em um contexto de exílio em terras cuja cultura era tão diferente da sua. As odes que Amina lê em voz alta celebram "os feitos triunfais dos poetas suas tribos suas tendas suas palmeiras estrelas camelos amantes" (MIRANDA, 2011, p. 30) e até mesmo o Corão tio Naim, que é cristão, gosta que Amina leia.

O sábio então transmite uma importante lição a Amina acerca da literatura árabe, na qual procura dissolver uma visão estigmatizada de que ela seria pregadora do apocalipse e suja por conter descrições do amor erótico. Para ele, ao contrário, a literatura árabe é preciosa e "verdadeira mesmo feita de fantasia", uma vez que "expressa de modo espirituoso a alma de um povo inteiro feita de sabedoria" (MIRANDA, 2011, p. 30). A sentença final dessa reflexão de tio Naim é altamente representativa das ideias que tenho proposto neste trabalho: "A literatura árabe lembra da existência dos outros mundos além deste que podemos ver e tocar mas não compreender" (MIRANDA, 2011, p. 30). São esses outros mundos e verdades possiveis que reivindicam existência, visibilidade e legitimidade, universos culturais historicamente estigmatizados, apagados e reprimidos de forma violenta pela cultura ocidental eurocêntrica, tanto em Amrik como em Ponciá Vicêncio.

A oralidade, fortemente marcada na linguagem de Amrik, também é um tema que aproxima os dois romances. Em "Mil e uma noites", tio Naim explica à Amina que a literatura das montanhas e dos desertos "pode ser feita e usada por pessoas que não sabem ler nem escrever, mas se ouvem entendem e podem recontar que são histórias e mais histórias" (MIRANDA, 2011, p. 31). Pessoas que não sabem ler nem escrever ainda dispõem de outros recursos - como o barro e dança, conforme veremos mais adiante - para se comunicarem e transmitirem histórias e conhecimentos. Nesse sentido, é interessante o argumento de Quijano (2005) de que a perspectiva eurocêntrica vê a história humana como um movimento sequencial, evolucionista e unidirecional. A partir dessa ótica, a oralidade seria apenas um estágio a ser superado pelo sistema de escrita, supostamente superior por ser mais sofisticado. No entanto, nos sistemas de pensamentos não canônicos 
representados nas ficções, a tradição oral parece estar presente de forma não hierarquizada em relação ao domínio da cultura escrita.

Em "Lingua dos Lusis", contrapondo um "eles" a um "nós", tio Naim novamente empreende um trabalho de desestigmatização do povo libanês que imigra para o Brasil: "fazemos mesmo umas coisas erradas mas não somos o que eles pensam, libaneses são limpos, cultos, temos a Université dos jesuitas e a Universidade Americana, sabemos falar inglês grego francês, sabemos ler escrever" (MIRANDA, 2011, p. 52). O tio ainda chama a atenção para as contribuições de sua cultura para o mundo:

[...] inventamos álgebra astronomia matemática, os algarismos arábicos o alfabeto, [...] trouxemos para ocidentais a laranjeira o limoeiro o arroz, ensinamos ocidentais a melhor cultivar alfarrobeira e a oliveira, a criar cavalos, a plantar uvas, figos e imensas maçãs, a regar, pintar as unhas, fazer hortas de verduras e talhões de legumes, mais de seiscentas palavras à lingua dos lusis (MIRANDA, 2011, p. 52).

Assim como em outros momentos da narrativa, tio Naim deixa explícito o embate epistemológico de sua própria cultura com o pensamento ocidental, enfatizando as ciências, as artes, as práticas, as habilidades e diversos outros aportes provenientes dos povos de origem árabe.

Por fim, encontramos também uma comparação entre a caligrafia árabe e o alfabeto latino. Em "Carta", Amina manda chamar o caligrafo Habib Izar para ditar uma carta que quer enviar a seu grande amor, Chafic. Esse caligrafo é quem escreve "com sua bela letra os escritos de tio Naim" (MIRANDA, 2011, p. 114). Em Damasco, Habib Izar aprendeu com um prestigiado mestre que "as letras árabes eram as mais completas e belas do mundo, não simples sons mas desenhos da alma do povo" (MIRANDA, 2011, p. 114). Essa definição da caligrafia árabe contrasta com sua visão do "alfabeto dos ocidentais" no capitulo seguinte: "tão sem beleza e espiritualidade" (MIRANDA, 2011, p. 115).

Desse modo, a recorrente crítica à imagem eurocêntrica sobre o Oriente e as reflexões acerca da literatura e da caligrafia árabe, da tradição oral e das técnicas e saberes produzidos pelos povos de origem árabe, assim como em Ponciá Vicêncio, parecem operar como respostas ativas à tendência ocidental de universalizar os seus sistemas de conhecimentos e valores.

\section{Saberes e memórias do barro e da dança}

No excerto selecionado para epígrafe deste trabalho, Amina tem a sensação de que não sabe mais pensar e de que o raciocínio se torna infinitamente inferior ao que se passa em seu interior. Essa reflexão da personagem traz uma interessante inversão na tradicional hierarquia ocidental, em que a razão é superior a outras formas de entender o mundo. Embora haja circunstâncias que exigem a habilidade de organizar e relacionar informações por meio de uma lógica racional, existem outros saberes disponiveis que não necessariamente estão ligados a operações puramente mentais. Inclusive, em alguns contextos, essas outras capacidades são muito mais plurais e produtivas em termos de conhecimento e memória do que o próprio raciocínio em sua acepção ocidental. É por essa razão que, neste tópico, faço emergir dos romances as potências que emanam do barro, em Ponciá Vicêncio, e da dança, em Amrik - saberes que, nessas ficções, são respostas ativas a contextos de colonização, exploração, opressão, dominação, silenciamento e violência.

\subsection{Ponciá Vicêncio}

O barro (ou argila) e o trabalho manual que o transforma em obras de cerâmica assume alguns papéis importantes na narrativa de Ponciá Vicêncio: uma habilidade legada pela mãe para a filha; um fragmento de memória que, no presente, conecta os membros da família ao passado em que estavam juntos e serve como fio de esperança para o reencontro no futuro; e, por fim, um objeto que conta partes de uma história coletiva, uma história que tenta sobreviver em meio aos esforços colonizadores de calar vozes e invisibilizar narrativas não canônicas.

Já desde a infância, Ponciá busca barro na beira do rio e, com o material, a sua mãe faz panelas, potes e bichinhos de barro. Depois de secas, as peças são 
colocadas para assar em um forno de barro, do qual saem trabalhos duros, fortes e custosos de quebrar. Ponciá observa a mãe e também passa a trabalhar habilmente o barro. Certa vez, para a surpresa da familia, molda um homenzinho de barro igual ao falecido avô, que a mãe, assustada e aflita, guarda no fundo de um caixote (EVARISTO, 2018, p. 20). O pai, por sua vez, examina bem o homem-barro e devolve-o à Ponciá, sem fazer nenhum gesto de aprovação ou reprovação, pois reconhece que aquele era um trabalho da filha para ela mesma, que não podia ser dado ou vendido (EVARISTO, 2018, p. 21). O homem-barro acompanhará Ponciá ao longo de toda a narrativa.

Adulta, recém-chegada à cidade, a protagonista aborda senhoras que saem da igreja em busca de alguém que precise de seus serviços. Nesse momento, informa - como quem comunica as suas habilidades em uma entrevista de emprego - que sabe lidar muito bem com o barro, pois este é o saber herdado de sua mãe na roça, o saber que leva para a cidade e é o que, a principio, ela tem para oferecer. Como era de se esperar, Ponciá não consegue um serviço no qual possa trabalhar o barro, mas o abecedário que aprendeu com os missionários em sua infância é agora de extrema utilidade: uma das senhoras que sai da igreja the entrega um pedaço de papel com o endereço de uma prima que talvez precise de Ponciá nos afazeres da casa e ela, feliz, é capaz de lê-lo e consegue o trabalho (EVARISTO, 2018, p. 38).

Quando a narrativa está centrada no presente da protagonista, a memória do barro é o que conecta Ponciá com seu passado e a familia deixada para trás. Observando com desgosto o cômodo onde vive com seu homem, relembra a casa de chão de barro batido onde vivia em sua infância e pensa nos utensílios de cozinha, também feitos de barro (EVARISTO, 2018, p. 23). Esses tempos de chão de barro batido remetem à fase da vida em que Ponciá gostava de ser mulher e era feliz. Eram os tempos em que a mãe vivia "entretida cantando com as suas vasilhinhas de barro", que eram divididas entre as que eram para vender e as que eram para presentear (EVARISTO, 2018, p. 24).

Apesar dessas nostálgicas lembranças vividas no presente, no momento que resolveu deixar o povoado onde havia nascido, Ponciá estava cansada até de "trabalhar o barro com a mãe, de ir e vir às terras dos brancos e voltar de mãos vazias" (EVARISTO, 2018, p. 30). Assim, em sua repentina partida para a cidade, acaba esquecendo de levar seu homem-barro (EVARISTO, 2018 p. 36). No presente, a recordação do trabalho esquecido traz junto a lembrança da mãe e do irmão, suscitando em Ponciá "um peso no coração, uma tristeza funda, um mau presságio" (EVARISTO, 2018, p. 36). Por isso, depois de muitos anos de trabalho na cidade, Ponciá consegue juntar um dinheiro e retorna ao povoado (EVARISTO, 2018, p. 41), onde encontra a casinha de pau a pique ainda de pé, marcada pela ausência da mãe e do irmão, mas com o chão de barro batido limpo e as vasilhas de barro da mãe arrumadas na prateleira (EVARISTO, 2018, p. 43). Antes de ir embora, pega o homembarro - que está entre pranto e risos - e o enrola em folha de bananeira e palhas secas, tal como sua mãe lhe havia ensinado, para então guardá-lo "carinhosamente no fundo da trouxa" (EVARISTO, 2018, p. 50). Mais tarde, Luandi também retorna ao povoado depois de ter partido para a cidade e se depara com a casa vazia (EVARISTO, 2018, p. 75). Assim como a irmã, encontra intactas as canequinhas de barro de cada membro da família e se assusta ao constatar que o homem-barro não está mais lá.

Nessa viagem ao povoado, enquanto espera o trem de volta para a cidade, Ponciá passa alguns dias nas "terras dos negros", nas quais encontra os trabalhos de barro feitos por ela e sua mãe no passado (EVARISTO, 2018, p. 54). A mãe passa por um processo semelhante nos anos de suas andanças de povoado em povoado: ela também encontra trabalhos de barro seus e de Ponciá, e sabe reconhecer perfeitamente qual obra é de quem. Com a devida distância, consegue finalmente admirar o que suas mãos tinham feito. No entanto, em suas peregrinações, não toca na massa nem trabalha o barro (EVARISTO, 2018, p. 72), como se fosse necessária a presença da filha para que essas criações façam sentido.

De volta à cidade, Ponciá mostra ao homem 
por quem está enamorada seu homem-barro (EVARISTO, 2018, p. 55). Ele, no entanto, não tem coragem de encarar a estátua: "Olhou de soslaio para o trabalho na mão da mulher. Como ela parecia com a imagem de barro que estava a segurar" (EVARISTO, 2018, p. 57). Ponciá começa a ter incômodas coceiras entre os dedos das mãos, que exalam cheiro de barro, o mesmo cheiro de seu homem-barro (EVARISTO, 2018, p. 64-65). Com isso, chega à seguinte conclusão: "Era o Vô Vicêncio que tinha deixado aquele cheiro" e, portanto, "ela não tinha perdido o contato com os mortos". Era um sinal "de que encontraria a mãe e o irmão vivos" (EVARISTO, 2018, p. 65). Assim, os efeitos causados pelo contato com o homem-barro não apenas lembram Ponciá de suas raízes, mas é também o que lhe dá esperança para o futuro e lhe assegura que encontrará a mãe e o irmão vivos.

Luandi, por sua vez, pensa na família e se lembra de que, no passado, a irmã trabalhava bem o barro, que "Tinha os dedos espertos, fazedores de coisas bonitas, mais do que os da mãe" (EVARISTO, 2018, p. 63). Há um momento na narrativa em que o soldado Nestor leva Luandi a uma exposição de arte popular no salão de um clube, cujos trabalhos são todos de barro. 0 passeio é uma surpresa para Luandi que, quando descobre o que vão fazer, sente a saudade da mãe e da irmã pular de forma inesperada e violenta (EVARISTO, 2018, p. 88). Enquanto contempla "os objetos de seu passado presente", sente aflorar em suas lembranças a vida da roça. O climax ocorre quando Luandi encontra trabalhos de barro feitos por sua mãe e sua irmã, "Criações feitas, como se as duas quisessem miniaturar a vida, para que ela coubesse e eternizasse sobre o olhar de todos, em qualquer lugar" (EVARISTO, 2018, p. 89). O fato de que aquelas criações, diferentemente de outras da exposição, estão com a devida indicação de autoria o emociona (EVARISTO, 2018, p. 90). Mais adiante, Luandi determina que um dia "voltaria ao povoado e tentaria recolher alguns trabalhos" da irmã e da mãe, pois eram "trabalhos que contavam partes de uma história. A história dos negros talvez" (EVARISTO, 2018, p. 107).

Já a mãe, quando pensa na partida dos filhos e no próprio envelhecimento, com o coração dolorido, faz a seguinte comparação: "Era como se tivesse dentro do peito um grande pote de barro, no qual armazenasse todas pessoas queridas, e esta vasilha um dia tivesse quebrado, partido" (EVARISTO, 2018, p. 65). Assim como o irmão de Ponciá, imagina a filha já crescida e se lembra de sua habilidade com o barro. Reflete que, desde pequena, Ponciá já sabia qual era a melhor massa, a mais macia, a mais obediente e "reconhecia aquela que aceitava de bom grado o comando das mãos, traduzindo em formas os desejos de quem cria. Ela conhecia de olhos fechados a matéria do rio" (EVARISTO, 2018, p. 65).

Quando a mãe chega à cidade pela primeira vez em sua vida, temerosa, mas com a certeza de encontrar os filhos, pondera: "não sabia ler, mas sabia falar" (EVARISTO, 2018, p. 100). Ao mesmo tempo que reconhece a importância da leitura para dar conta das demandas próprias de uma cidade, sente de algum modo que o conhecimento que já tem, a fala, se associada com a "coragem que teria que fabricar" (EVARISTO, 2018, p. 100), lhe permitirá chegar aonde deseja: encontrar os filhos. E de fato é o que acontece. A despeito de não saber ler, podia se expressar por meio da fala, da oralidade - e até mesmo por meio do próprio corpo, que é lido pelo soldado Nestor na estação de trem: "contemplava de longe aquela mulher de andar temeroso, agarrada a uma pequena trouxa e que vinha na direção dele" (EVARISTO, 2018, p. 100).

\subsection{Amrik}

Os saberes que emanam do corpo nos remetem ao capitulo de Amrik intitulado "Joia no Escrínio", em que a protagonista reflete sobre a diferença que nota existir entre a sua familia e as outras familias da mesma aldeia. Há uma espécie de segregação que a narradora, nesse momento ainda criança, não entende muito bem e se pergunta se as outras pessoas da aldeia consideram a sua família "uma gente da lua" devido ao fato de sua avó Farida ter sido dançarina. Amina percebe que ser dançarina acaba provocando nas pessoas reações aparentemente contraditórias: 
por um lado, está ligada ao sagrado; por outro, a jovem e suntuosa dançarina torna as noites mais luxuriantes e leva os homens a imaginarem o que há debaixo dos panos que cobrem o seu ardente corpo, o qual pode assumir o seu lado frivolo e ser usado como uma "artimanha das mulheres para aprisionar espíritos de homens fracos e exaurir sua virilidade" (MIRANDA, 2011, p. 18), como de fato acaba acontecendo mais adiante com o mascate Abraão ao ver Amina dançando em seu casamento.

Sobre essas delicadas ambiguidades do corpo e da dança, vovó Farida transmite a Amina, de forma oral, alguns de seus ensinamentos: "o corpo não pode ser rejeitado nem esquecido ele não é inferior deve ser desejado amado como uma joia de familia precisa ser guardado no escrinio, quem despreza o corpo sentirá a vingança de Deus" (MIRANDA, 2011, p. 18). Para a avó, a dança assume um sentido de contemplação religiosa, devendo ser vista em seu lado de devoção, ritual: "dança é vinho e vinho pode ser tomado em comunhão com o sangue de Deus ou pode ser tomado nas festas dos clientes de Baco tirando as suas baforadas" (MIRANDA, 2011, p. 18). Recorrendo à mitologia greco-romana, considerada pagã pela doutrina cristã, vovó Farida evoca como exemplo Baco, deus do vinho, da ebriedade e dos excessos sexuais, para contrapor ao uso que ela considera adequado para a dança: em comunhão com Deus.

Em "Serpente do Nilo", a avó adivinha que Amina vai ser dançarina por algumas caracteristicas que parece considerar imprescindiveis para a prática da dança: "olhar de uma serpente do Nilo, o passo leve, estudados intervalos no tempo, olhar de desdém como olhasse um deserto distante" (MIRANDA, 2011, p. 20). Outras mulheres também sentem desejo de dançar com elas, e o pai de Amina condena a dança descrevendo-a como uma "lascivia de muçulmanas", ao que a avó responde: "tudo o que fazemos de tradição é sagrado" (MIRANDA, 2011, p. 20), reforçando a ideia da dança como uma prática sagrada cuja tradição deve continuar sendo reproduzida.

Assim, a despeito da desaprovação masculina, os ensinamentos prosseguem. Vovó Farida mostra como se vestir, ensina como se movimentar e explica que a dança pode "fazer um homem andar mil passos num vale ou atravessar um deserto sem camelo" (MIRANDA, 2011, p. 20). Aqui, o caráter sagrado que Farida atribui à dança parece não estar relacionado a um desprendimento de si mesma em nome de uma devoção a uma entidade externa e superior. Ao contrário: quando diz "dança de apreciar e dança de sentir bem no corpo e na alma" (MIRANDA, 2011, p. 20), vovó Farida mostra a preocupação com a autonomia e o bem-estar da própria dançarina em relação a seu corpo e a sua alma.

Mais adiante, em "Ghawazee", Amina tece as suas próprias reflexões sobre a dança e o corpo: "há uma arte em harmonizar os gestos, a forma ideal, em descobrir a vocação de cada parte do corpo, o mais perfeito uso das mãos, do queixo, dos ombros, dos pés, o espaço que os quadris devem ocupar, em que lugar se joga a transparência de um véu" (MIRANDA, 2011, p. 21). A arte a que se refere é uma arte de espaço, de espírito, de anatomia, isto é, implica uma série de conhecimentos e habilidades, tanto técnicas quanto criadoras. Nesse sentido, é interessante a hipótese sustentada por Leda Martins (2003) de que o corpo em performance remeteria a um local de inscrição de conhecimento, o qual se grafa no movimento, na coreografia. Para a autora, a memória do conhecimento é recriada e transmitida constantemente "pelos repertórios orais e corporais, gestos, hábitos, cujas técnicas e procedimentos de transmissão são meios de criação, passagem, reprodução e de preservação de saberes" (MARTINS, 2003, p. 67).

Para Amina, "a dança tem sua alma" (MIRANDA, 2011, p. 21), e a alma é um elemento norteador na vida da protagonista, sendo retomado continuamente ao longo da narrativa. A dança, que pode ser vista através dos olhos, não deve ser lida simplesmente como uma manifestação da beleza do corpo: isso seria deixar-se iludir pelas aparências e por seus usos frivolos, conforme alertou vovó Farida. Não: o corpo tem uma alma e a alma é o que está presente por debaixo da camada exterior da dança, é o que se ensina para além daquilo que se vê.

Mais adiante, em "Óleo de Sésamo", tio Naim diz a Amina que ela deve ir para a mâdrassa (escola ou instituição superior) a fim de ter contato 
com campos clássicos do conhecimento, como latim, álgebra, matemática e astronomia. Para o tio, "não basta saber dançar e bordar rosas de seda", mas Amina não está de acordo: "sei fazer contas e sei ler e escrever, basta, eu sabia palavras francesas que aprendera com tio Naim, [...] mas para que lembrar de palavras francesas? e inglesas? não gosto de estudar, tio Naim, prefiro dançar" (MIRANDA, 2011, p. 69).

A despeito das boas intenções do tio, que sempre a deixou livre e a educou para o mundo, ensinando-lhe a ler e a escrever, falando-lhe sobre música, filosofia, matemática, astronomia, Amina reconhece que tudo tinha sido em vão: "eu tinha sido forjada na dança e na cozinha minha alma feita nas mãos padeiras de vovó sovada alma massa de pão, meu corpo dançava mesmo quando eu andava ou metia os pés no regato" (MIRANDA, 2011, p. 27). É interessante a escolha pelo verbo forjar, que significa, de modo literal, fundir ou modelar o metal na forja. Apesar de poder ser maleável como o ferro e poder absorver outros saberes, Amina parece sentir que a sua subjetividade foi moldada na dança e na cozinha, a partir dos saberes da avó, e seu corpo, com essa memória inscrita, dança involuntariamente, em cada movimento seu.

Enquanto para o tio Naim a dança é insuficiente em termos de conhecimento, Amina parece seguir em sintonia com os ensinamentos de avó, que dizia que o corpo "não pode ser rejeitado nem esquecido ele não é inferior" (MIRANDA, 2011, p. 18). O corpo, portanto, não é inferior aos outros elementos que compõem um ser, e sua expressão, a dança, assim como a literatura árabe defendida pelo tio como "expressão da alma de um povo inteiro feita de sabedoria" (MIRANDA, 2011, p. 30), também serve como abrigo da memória, vetor de saberes, manifestação da alma e da resistência de um povo: "se os turcos nos dominam e nos ensinam suas mesquinhas conveniências e suas seitas mais ardidas, resistimos com a nossa língua e a nossa culinária, também a música e a dança" (MIRANDA, 2011, p. 130).

Mas, afinal, a que possibilidades de reflexão nos levam todos esses entrecruzamentos de saberes em Ponciá Vicêncio e Amrik?

\section{Por uma ecologia dos saberes}

Retomando as discussões levantadas no início deste artigo, como resposta ativa à autorreprodução do pensamento abissal, Santos (2009, p. 41) sugere uma resistência epistemológica, uma vez que "não existe justiça social global sem justiça cognitiva global". O autor defende uma amplificação simbólica de sinais, pistas e tendências que indiquem novas constelações de sentido no que se refere à compreensão e à transformação do mundo, em uma iniciativa de globalização contrahegemônica. Isso, no entanto, deve ser feito sem que se ambicione a completude, pois, quanto mais identificarmos compreensões não ocidentais, com mais força se evidenciará o fato de que há ainda mais compreensões a serem identificadas e que são virtualmente infinitas as possibilidades de compreensões hibridas, isto é, as que mesclam saberes ocidentais com conhecimentos não ocidentais.

O pensamento pós-abissal, enquanto alternativa pós-capitalista progressista, deve ter como eixo central uma ruptura drástica com a monocultura da ciência moderna, confrontando-a com uma ecologia dos saberes. Santos (2009) ressalta que se trata de uma ecologia por reconhecer a pluralidade de conhecimentos heterogêneos, com interações sustentáveis e dinâmicas entre si. Para tanto, é preciso renunciar a qualquer ilusão de uma epistemologia geral, pois existem no mundo distintas maneiras de conhecimento de matéria, sociedade, vida e espírito, assim como diversos critérios para avaliar o que é conhecimento válido ou não. Nessa perspectiva, o autor alerta que buscar credibilidade para saberes não científicos não implica deslegitimar o conhecimento científico, e sim sua utilização contra-hegemônica. A ideia é explorar as práticas alternativas, que têm ganhado visibilidade por meio das epistemologias feministas e pós-coloniais, e promover a interação entre esses diversos saberes.

Na ecologia de saberes descrita por Santos (2009), todas as construções cognitivas são incompletas e apresentam os seus limites internos e externos. 
Sua credibilidade, portanto, é mensurada por sua capacidade de proporcionar, ajudar ou impedir intervenções no mundo, já que nenhuma forma singular de conhecimento está apta a responder pela totalidade de intervenções possiveis no real. O importante é que os vários tipos de saberes disponham de uma copresença igualitária, a partir de uma coexistência de diferentes temporalidades em diferentes práticas de conhecimento.

Outra característica de destaque da ecologia dos saberes é o reconhecimento da necessidade de reavaliar as relações entre os saberes. Em contraposição a uma hierarquia única, universal e abstrata, Santos (2009) indica que é preciso favorecer hierarquias que dependam do contexto, levando em conta os resultados concretos que se pretende atingir por meio das diversas formas de conhecimento. A hegemonia das epistemologias abissais do Norte global, que há séculos fiscaliza as fronteiras do conhecimento relevante, tem trazido como consequência um epistemicídio que acaba por desperdiçar uma riqueza de experiências cognitivas. Desse modo, a ecologia dos saberes teria a tarefa de recuperar algumas dessas experiências que fazem parte de uma diversidade não canônica do mundo.

Nesse sentido, procuramos identificar a presença de compreensões não ocidentais e hibridas nos romances selecionados, observando de que maneira se relacionam e qual o seu poder de intervenção no real. Promovendo uma releitura e uma re-visão das raizes culturais no Brasil do ponto de vista de duas escritoras nascidas em território historicamente colonizado, as obras revelam uma narrativa contra-hegemônica para responder aos discursos e à herança colonial moderna, em sua tentativa de universalizar os conhecimentos e valores ocidentais.

Nas duas obras, pudemos observar diversas dinâmicas nas relações entre saberes do campo/ saberes da cidade; saberes populares/ saberes científicos; ancestralidade, oralidade e tradições não ocidentais/ saberes, valores e tradições do Ocidente branco; saberes da dança e do barro/ racionalidade eurocêntrica. No contexto latino-americano, ainda que a principio esses conhecimentos possam parecer engessados em binarismos rígidos e hierárquicos, que alçam a epistemologia hegemônica do colonizador a um patamar supostamente superior e de objetividade infalivel, o que encontramos nos romances foi uma ecologia dos saberes tal como a reivindicação de Boaventura de Sousa Santos (2009). Nas narrativas, todos os conhecimentos mobilizados, seja dos colonizados ou dos colonizadores, sejam ocidentais ou não, na prática são movediços e - não sem conflitos se atravessam continuamente.

\section{Referências}

EVARISTO, Conceição. Ponciá Vicêncio. 3. ed. Rio de Janeiro: Pallas, 2018.

GONZALEZ, Lélia. A categoria político-cultural de amefricanidade. Tempo Brasileiro. Rio de Janeiro, n. 92/93, p. 69-82, jan./jun. 1988

MACHADO, Bárbara Araújo. "Recordar é preciso": Conceição Evaristo e a intelectualidade negra no contexto do movimento negro brasileiro contemporâneo (1982-2008). 2014. 130 f. Dissertação (Mestrado) - Instituto de Ciências Humanas e Filosofia, Departamento de História, Universidade Federal Fluminense, Niterói, RJ, 2014.

MACIEL, Nahima. Conceição Evaristo: 'A literatura está nas mãos de homens brancos'. Correio Braziliense, Brasilia, DF, 15 jul. 2018. Disponivel em: https://www.correiobraziliense.com.br/app/noticia/ diversao-e-arte/2018/07/15/interna_diversao_ arte,694873/entrevista-conceicao-evaristo.shtml. Acesso em: 5 jul. 2019.

MALDONADO-TORRES, Nelson. Analítica da colonialidade e da decolonialidade: algumas dimensões básicas. In: BERNARDINO-COSTA, Joaze; MALDONADO-TORRES, Nelson; GROSFOGUEL, R. (org.). Decolonialidade e pensamento afrodiaspórico. Belo Horizonte: Autêntica, 2018. p. 44-93. (Coleção Cultura Negra e Identidades).

MARTINS, Leda. Performances da oralitura: corpo, lugar da memória. Letras, Santa Maria, n. 26, jun. 2003. Disponivel em: https://periodicos.ufsm.br/letras/article/view/11881/7308. Acesso em: 12 jul. 2019

MIRANDA, Ana. Amrik. 2. ed. São Paulo: Companhia das Letras, 2011.

MIRANDA, Ana. 'A sensação é que todos os meus livros são resultado de sonhos'.'.Entrevista cedida a] Maurício Meireles. O Globo, Rio de Janeiro, $21 \mathrm{fev}$. 2014. Disponivel em: https://oglobo.globo.com/cultura/ana-miranda-sensacao-que-todos-os-meus-livros-sao-resultado-de-sonhos-11668799. Acesso em: 5 jul. 2019. 
QUIJANO, Anibal. Colonialidade do poder, Eurocentrismo e América Latina. In: LANDER, E. A colonialidade do saber: eurocentrismo e ciências sociais: perspectivas latino-americanas. Buenos Aires: Clacso, 2005.

SANTOS, Boaventura de Sousa. Para além do pensamento abissal: das linhas globais a uma ecologia de saberes. In: SANTOS, Boaventura de Sousa; MENESES, Maria Paula. (Orgs.). Epistemologias do Sul. Coimbra: Almedina, 2009.

\section{Endereço para correspondência:}

Aline Veingartner Fagundes

Rua Eng. Agronômico Andrei Cristian Ferreira, s/n, Trindade, Florianópolis, CEP 88040-900.

\section{Aline Veingartner Fagundes}

Mestranda em Literatura no Programa de Pós-graduação em Literatura, na linha de pesquisa Crítica Feminista e Estudos de Gênero pela Universidade Federal de Santa Catarina (UFSC), Florianópolis, SC, Brasil, com bolsa da Coordenação de Aperfeiçoamento de Pessoal de Nivel Superior (CAPES). 